\title{
An Empirical Assessment of Participation and Decision Making by Rural Women in Agriculture and Livestock Activities
}

\author{
Rashmi Chaudhary ${ }^{1 *}$, Yasmin Janjhua ${ }^{2}$, Avineet ${ }^{3}$ and Krishan Kumar ${ }^{4}$ \\ Dept. of Business Management, College of Horticulture, Dr. Y. S. Parmar University of Horticulture and Forestry, Nauni, \\ Solan, H.P. (173 230), India
}

\author{
Corresponding Author \\ Rashmi Chaudhary \\ e-mail: rashmi.uhf@gmail.com
}

\author{
Article History \\ Article ID: IJEP0355 \\ Received in $01^{\text {st }}$ January, 2020 \\ Received in revised form $16^{\text {th }}$ January, 2020 \\ Accepted in final form $25^{\text {th }}$ January, 2020
}

\begin{abstract}
Women make essential contributions to agriculture and rural economic activities in all developing countries. Even though women contribute 60 to $80 \%$ of the labour in agriculture and animal husbandry, their involvement in selection of suitable crops and adoption of innovative and good management practices is very low. The study reported that sampled women respondents have shown participation in all the selected agriculture and livestock activities excluding marketing and financial management. The study put forth that very less households witness female participation in agriculture and livestock activities related decision making. Some of the important reasons for their subdued role in decision making in agricultural production could be lack of awareness about new opportunities and modern technologies, inadequate facilities for training and capacity building and poor access to extension workers for consultation whenever needed.
\end{abstract}

Keywords: Agriculture, decision making, livestock, participation, women

\section{Introduction}

Women form the backbone of agricultural rural economy in the developing countries. Women produce over $50 \%$ of the world's food and account for $43 \%$ of the agricultural labor force in developing countries (FAO, 2011). Women play key role in agricultural production, as subsistence farmers, crop growers, food processors, and livestock caretaker. The rationale for paying attention to gender inequality in agriculture emanates from empirical evidence that demonstrates the ways in which women are essential to improvements in household agricultural productivity, food security and nutrition security.

Women play a significant role in the sustainable development of the economy through their contribution in the household and through agricultural activities, often at par with men (Majumder and Shah, 2017). Considerable evidence also suggests that mothers' greater control over resources improves child outcomes-in particular, nutrition and education (Hallman, 2003 and Skoufias, 2005). Women's indigenous knowledge and skills are vitally necessary for food production and sustainable agriculture (Singh and Arora, 2010).

Empirical research has shown that empowering women can lead to improvements in their status both inside and outside the household including greater control over household resources; better mental health; reduced time constraints; and increased access to financial services, health care, skills development, income-earning opportunities, information about markets and legal rights all of which may, in turn, positively impact agricultural productivity, nutrition and food security (Zereyesus, 2017; Ross et al., 2015; Smith et al., 2003). The UN's Food and Agriculture Organization viewed that if women had the same access to productive resources as men, they could increase yields on their farms by $20-30 \%$ raising total agricultural output in developing countries by up to $4 \%$, which could in turn reduce the number of hungry people in the world by 12-17\% (Munshi, 2017). Women empowerment is considered as the key to improve agriculture productivity through multiple roles in agriculture sector, as cultivators, entrepreneurs and labourers.

Women, although often not visible in national statistics, have an important role to play in the agricultural production and food security in light of continued population growth and the prevailing youth bulge. Despite women's important role in the agricultural sector in developing countries yet the irony is that they remain one of the most vulnerable groups. The constraints and opportunities that women face in agriculture today vary across regions and countries, depending on the socio-cultural and agro-ecological contexts. Gender norms, beliefs and behaviors limit women's decision-making power related to production, assets, resources, income, leadership and membership in groups, and how they spend their time. The women are found to lag behind men in respect of access to, control over and utilization of productive resources such 
as land, livestock, labour, education, extension and financial services, and technology (Ahearn and Tempelman, 2010; Zereyesus, 2017; Kassie et al., 2015; Oseni et al., 2015).

The women's ability to generate income in the agricultural sector is severely constrained by their limited use, ownership, and control of productive physical and human capital. There is an average gender wage disparity in all activities, with women earning only $70 \%$ of men's wage. Additionally, many women participate in agricultural work as unpaid subsistence labor (Khyade and Khyade, 2016). The results of a study noted that women are disempowered in two major domains of agriculture-resources i.e. access and decision-making and leadership i.e. group membership (Gupta et al., 2017). In the context of a patriarchal gender biased culture women are less likely than men to define their activities as work, they are less likely to report themselves as being engaged in agriculture and they work, on average, longer hours than men (FAO, 201011). In this backdrop, present study was conducted to study the participation of rural women in decision making regarding agriculture operations and livestock management.

\section{Materials and Methods}

The study was conducted in four villages of District Shimla in Himachal Pradesh. The target population for the study comprised of farm women who are primary decision maker in the household. A total of 80 respondents were selected for the study and a systematic random sampling technique was used to select 20 sample respondents from each village. Data were collected using pre-structured questionnaire developed by the researchers after reviewing some previous work. The extent of rural women participation in agriculture and livestock were assessed by using a three point continuum namely 'Regularly,' 'Occasionally' and 'Not at all' which was assigned scores of 2, 1 and 0, respectively. For the purpose of ranking of different activities performed by rural women, the frequency of responses from each of the three point continuum of a specific activity under major activity was tabulated and multiplied by concerned score. Then, they were added together to get the total score for each specific activity for the purpose of their ranking (Sailaja and Reddy, 2003). For analyzing the underlying pattern of decision making, percentage of households with male, female and joint decision making has been calculated for each decision area.

\section{Results and Discussion}

Distribution of the respondents according to the extent of participation in selected agriculture activities along with participation indices and rank order is depicted in Table 1. Analysis of the data reveals that substantial percentage (63.75\%) of the respondents participated 'regularly' in hand weeding. Further analysis depicts that overwhelming percentage of respondents participate occasionally in irrigation (72.5\%), storage (71.3\%) and harvesting (70\%). However, a

Table 1: Participation of farm women in selected agriculture activities

\begin{tabular}{|c|c|c|c|c|c|c|c|c|}
\hline \multirow[t]{3}{*}{ Activity } & \multicolumn{6}{|c|}{ Extent of participation } & \multirow{3}{*}{$\begin{array}{l}\text { Participation } \\
\text { Indices }\end{array}$} & \multirow{3}{*}{$\begin{array}{l}\text { Rank } \\
\text { order }\end{array}$} \\
\hline & \multicolumn{2}{|c|}{ Regularly } & \multicolumn{2}{|c|}{ Occasionally } & \multicolumn{2}{|c|}{ Not at all } & & \\
\hline & No. & $\%$ & No. & $\%$ & No. & $\%$ & & \\
\hline Land preparation & 2 & 2.5 & 36 & 45 & 42 & 52.5 & 40 & 7 \\
\hline Preparation of seed beds & 15 & 18.75 & 46 & 57.5 & 19 & 23.8 & 76 & 3 \\
\hline Sowing/planting & 7 & 8.75 & 33 & 41.3 & 40 & 50 & 47 & 6 \\
\hline Application of ferti-lizers & 5 & 6.25 & 25 & 31.3 & 50 & 62.5 & 35 & 8 \\
\hline Irrigation & 14 & 17.5 & 58 & 72.5 & 8 & 10 & 86 & 2 \\
\hline Application of pesti-cides & 3 & 3.8 & 19 & 23.8 & 58 & 72.5 & 25 & 9 \\
\hline Hand weeding & 51 & 63.75 & 21 & 26.25 & 8 & 10 & 123 & 1 \\
\hline Harvesting & 4 & 5 & 56 & 70 & 20 & 25 & 64 & 4 \\
\hline Storage & 1 & 1.3 & 57 & 71.3 & 22 & 27.5 & 59 & 5 \\
\hline Marketing & 1 & 1.3 & 12 & 15 & 67 & 83.8 & 14 & 10 \\
\hline Keeping accounts & 1 & 1.3 & 8 & 10 & 71 & 88.75 & 10 & 11 \\
\hline
\end{tabular}

large majority of the respondents were 'not at all' engaged in keeping accounts (88.75\%), marketing (83.8\%) and application of pesticides (72.5\%). Perusal of the data reveals that overall the most prevalent activity preformed by the respondents is hand weeding followed by irrigation, preparation of seed beds, harvesting and storage. However their participation in keeping accounts and marketing is minimal.

Table 2 shows the pattern of decision making for agriculture activities. It is evident from the table that the decision of application of pesticides (91.3\%), financial management (71.25\%), marketing (58.8\%) and purchase/sale of agricultural tools/equipments is taken predominantly by men alone whereas land selection (72.5\%), crop selection (71.3\%), fertilizer application (71.3\%) and irrigation (68.8\%) decisions are taken jointly by men and women in majority households. Further, it is clear from the table that very less households 


\begin{tabular}{|c|c|c|c|c|c|c|}
\hline \multirow[t]{3}{*}{ Activity } & \multicolumn{6}{|c|}{ Decision makers } \\
\hline & \multicolumn{2}{|c|}{ Men } & \multicolumn{2}{|c|}{ Women } & \multicolumn{2}{|c|}{ Joint } \\
\hline & No. & $\%$ & No. & $\%$ & No. & $\%$ \\
\hline Land Selection & 20 & 25 & 2 & 2.5 & 58 & 72.5 \\
\hline Crop selection & 21 & 26.3 & 2 & 2.5 & 57 & 71.3 \\
\hline Application of fertilizers & 21 & 26.3 & 2 & 2.5 & 57 & 71.3 \\
\hline Application of Pesticides & 73 & 91.3 & 0 & 0 & 7 & 8.8 \\
\hline Purchase/Sale of agricultural tools/equipments & 44 & 55.0 & 1 & 1.3 & 35 & 43.8 \\
\hline Irrigation & 24 & 30.0 & 1 & 1.3 & 55 & 68.8 \\
\hline Hiring labour & 34 & 42.5 & 0 & 0 & 46 & 57.5 \\
\hline Marketing & 47 & 58.8 & 2 & 2.5 & 31 & 38.8 \\
\hline Financial management & 57 & 71.25 & 1 & 1.3 & 22 & 27.5 \\
\hline
\end{tabular}

witness female participation in agriculture activities related various livestock related activities along with participation decision making.

The extent of involvement of rural women participation in

indices and rank order is depicted in Table 3. It is put forth that a large percentage of sampled women are regularly involved

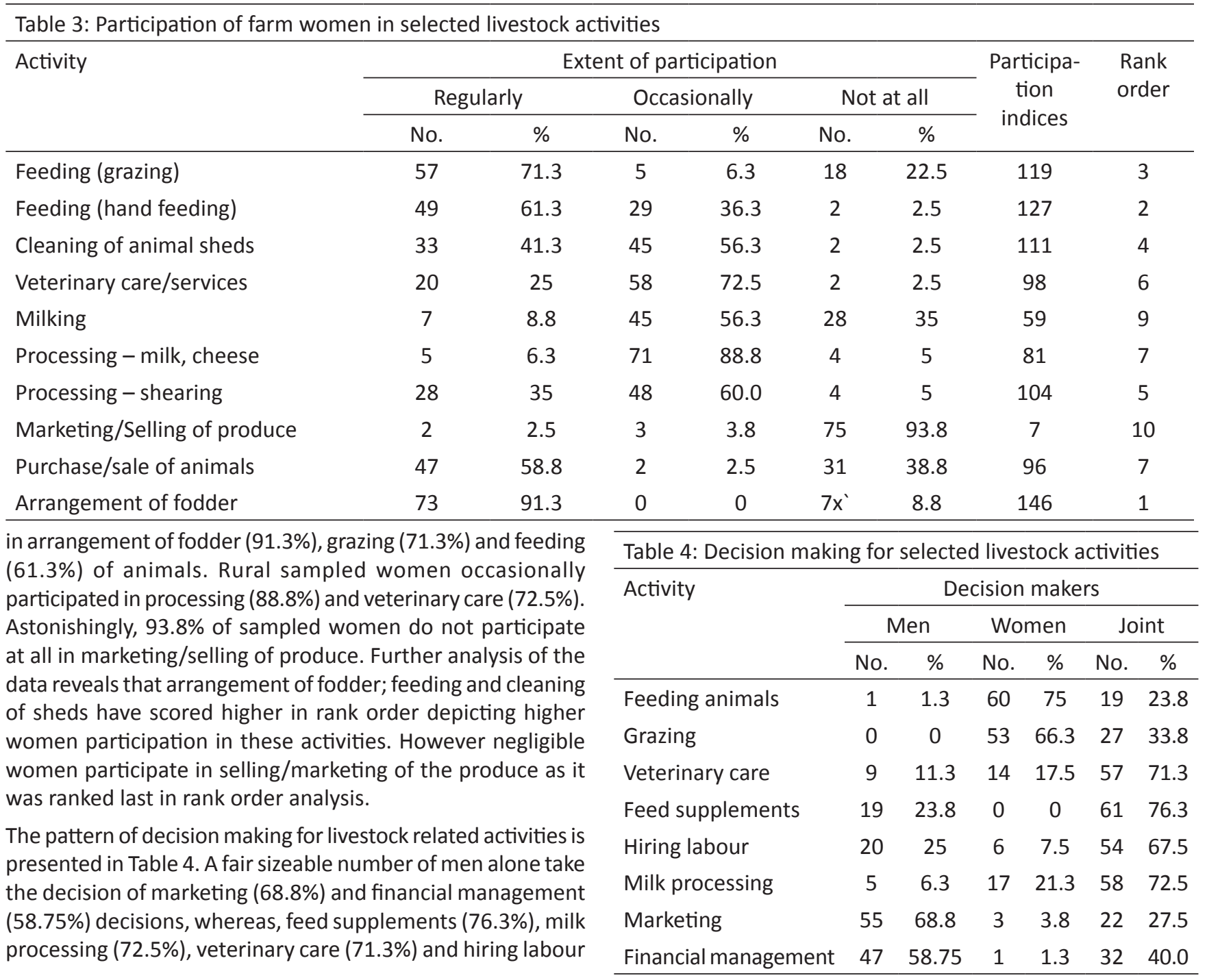


(67.5\%) decisions are jointly taken by men and women in the household. A large majority of the sampled respondents takes the decision of feeding (75\%) and grazing (66.3\%) animals. Analysis of the table reveals that most of the decisions are either taken by men or jointly by men and women except for the decision of feeding and grazing.

\section{Conclusion}

From the above study, it is that suggested that the participation of women should also be increased in agricultural decision making. Results indicate that women were more engaged in livestock tasks and not participating in managing the agricultural income and marketing related matters. Women should move forward to make decisions and use of income they are earning. Conscious efforts are needed for training of rural female agricultural workers. Government should provided good facilities to poor rural women for land, agricultural and livestock extension services.

\section{References}

Ahearn, M.C., Tempelman, D., 2010. Gender issues in agricultural and rural household well-being. Paper presented at the Third Global Conference on Agricultural and Rural Household Statistics-Washington, DC. Available from http://www.fao.org/fileadmin/ templates/ess/pages/rural/wye_city_group/2010/May/ WYE_2010.4.2_Ahearn_Tempelman_rev.pdf. Accessed in December 2018.

FAO (Food and Agriculture Organization of the United Nations), 2011. The state of food and agriculture 2010-2011. Women in agriculture: closing the gender gap for development. Available from http://www.fao.org/3/ i2050e/i2050e05.pdf. Accessed in December 2018.

FAO, 2010-11. The state of Food and agriculture. Available from http://www.fao.org/3/i2050e/i2050e01.pdf. Accessed in January 2019.

Gupta, S., Pinhali, P.L., Andersen, P.P., 2017. Women's empowerment in Indian agriculture: does market orientation of farming systems matter? Food Security 9, 1447-1463.

Hallman, K., 2003. Mother-father resources, marriage payments, and girl-boy health in rural Bangladesh. In Quisumbing, A.R. (Ed.), Household decisions, gender, and development: A synthesis of recent research (pp.
115-120). Baltimore, Johns Hopkins University Press for the International Food Policy Research Institute.

Kassie, M., Stage, J., Teklewold, H., Erenstein, O., 2015. Gendered food security in rural Malawi: Why is women's food security status lower? Food Security 7, 1299-320.

Khyade, V.B., Khyade, S.V., 2016. Indian Women in Agriculture. International Academic Journal of Social Sciences 3, 1-8.

Majumder, J., Shah, P., 2017. Mapping the role of women in Agriculture, Annals of Anthropological Practice 41, 46-54.

Munshi, S., 2017. It's time to recognize and empower India's women farmers. Available from https://www.weforum. org/agenda/2017/10/indias-women-farmers/. Accessed in February 2019.

Oseni, G., Corral, P., Goldstein, M., Winters, P.C., 2015. Explaining gender differentials in agricultural production in Nigeria. Agricultural Economics 46, 285-310.

Ross, K.L., Zereyesus, Y.A., Shanoyan, A., Amanor-Boadu, V., 2015. The health effects of women's empowerment: recent evidence from northern Ghana. International Food and Agribusiness Management Review 18, 127-44.

Sailaja, A., Reddy, M.N., 2003. Changing needs of Farm Women in Agriculture, MANAGE Extension Research Review, Rajendranagar, Hyderabad, India, 164-175.

Singh, S., Arora, R., 2010. Ergonomic Intervention for Preventing Musculoskeletal Disorders among Farm Women. Journal of Agriculture Science 12, 61-71.

Skoufias, E., 2005. PROGRESA and its impacts on the welfare of rural households in Mexico. Food consumption and nutrition division discussion paper no. 139. International Food Policy Research Institute. Available from https:// www.google.com/url?sa=t\&rct=j\&q=\&esrc=s\&source. Accessed in March 2019.

Smith, L.C., Ramakrishnan, U., Ndiaye, A., Haddad, L., Martorell, R., 2003. The importance of women's status for child nutrition in developing countries. IFPRI Research Report 3. International Food Policy Research Institute, Washington, DC.

Zereyesus, Y.A., 2017. Women's empowerment in agriculture and household level health in northern Ghana: a capability approach. Journal of International Development 29, 899-918. 